\title{
Zespół aktywacji makrofagów w chorobie Stilla u dorosłych - opis przypadku
}

\section{Macrophage activation syndrome in the course of adult-onset Still's disease - a case report}

\author{
Marzena Lewandowska, Marek Brzosko $\bowtie$ \\ Pomorski Uniwersytet Medyczny w Szczecinie, Klinika Reumatologii, Chorób Wewnętrznych i Geriatrii, ul. Unii Lubelskiej 1, 71-252 Szczecin \\ $\triangle$ brzoskom@pum.edu.pl
}

\begin{abstract}
Introduction: Macrophage activation syndrome (MAS) is a rare complication of autoimmune diseases. The background of the diseases is immune system dysfunction. The disease is characterized by varying symptomatology and the different dynamics of accumulation of symptoms.

Case report: A female patient diagnosed with adult-onset Still's disease was admitted to the hospital because of fever, weakness, skin rash and dyspepsia which had lasted for several days. Diagnostic tests revealed the presence of anti-nuclear antibodies, pancytopenia, hypertriglyceridemia, hyperferritinemia, hypofibrinogenemia, elevated activity of liver enzymes, and increased levels of C-reactive protein. The initial treatment with empirical
\end{abstract}

antibiotic therapy and intravenous pulses of methylprednisolone was unsuccessful and provided no improvement. On the basis of bone marrow cytological examination, the diagnosis of MAS was established. The patient was treated with dexamethasone and cyclosporine A with improvement. The patient was followed up in the rheumatology out-patient department for 20 months without the relapse of MAS.

Conclusion: Macrophage activation syndrome is a rare, dangerous complication of autoimmune diseases, requiring rapid diagnosis and aggressive treatment.

Keywords: secondary haemophagocytic syndrome; haemophagocytic lymphohistiocytosis; adult-onset Still's diseases; dexamethasone; cyclosporine.

\begin{abstract}
ABSTRAKT
Wstęp: Zespół aktywacji makrofagów (MAS) jest rzadkim powikłaniem chorób autoimmunologicznych. U jego podstawy leżą zaburzenia funkcjonowania układu immunologicznego. Symptomatologia może być różna, z różną dynamiką narastania objawów.

Opis przypadku: Kobieta z ustalonym rozpoznaniem choroby Stilla u dorosłych została przyjęta do kliniki z powodu gorączki trwającej od 7 dni, osłabienia, wysypki obejmującej skórę całego ciała oraz objawów dyspeptycznych. W trakcie diagnostyki stwierdzono pancytopenię, hipertrójglicerydemię, hiperferrytynemię, hipofibrynogenemię, podwyższoną aktywność wszystkich enzymów wątrobowych, podwyższone stężenie białka C-reaktywnego, a także obecność przeciwciał przeciwjądrowych.
\end{abstract}

W leczeniu początkowo zastosowano empiryczną antybiotykoterapię oraz pulsy metyloprednizolonu, co jednak nie przyniosło poprawy. Po otrzymaniu wyniku badania cytologicznego szpiku, w którym opisano pobudzoną fagocytozę mogącą odpowiadać zespołowi MAS, do leczenia włączono deksametazon oraz cyklosporynę A i wówczas stwierdzono poprawę. Chora zostawała pod stałą opieką przyklinicznej poradni reumatologicznej i od 20 miesięcy nie nastąpił nawrót MAS.

Wnioski: Zespół aktywacji makrofagów jest rzadkim, groźnym powikłaniem chorób autoimmunologicznych wymagającym szybkiego rozpoznania i agresywnego leczenia.

Słowa kluczowe: wtórne zespoły hemofagocytarne; limfohistiocytoza hemofagocytarna; zespół Stilla; deksametazon; cyklosporyna.

\section{WSTĘP}

Zespół aktywacji makrofagów (macrophage activation syndrome - MAS) jest rzadkim, poważnym powikłaniem układowych chorób tkanki łącznej. Należy do grona wtórnych zespołów hemofagocytarnych (hemophagocytic syndromeHS), inaczej zwanych limfohistiocytozą hemofagocytarną (hemophagocytic lymphohistiocytosis - HLH).

Nazwa zespołu aktywacji makrofagów jest zarezerwowana dla HLH wywołanych chorobami układowymi tkanki łącznej $[1,2,3,4,5,6,7,8,9,10,11,12]$. Najczęściej MAS jest opisywany w przebiegu młodzieńczego idiopatycznego zapalenia stawów (wg piśmiennictwa nawet 7-10\% chorych rozwija MAS), ale może występować także w przebiegu innych chorób, takich jak: choroba Stilla, reumatoidalne zapalenie stawów, toczeń rumieniowaty układowy, zespół Sjögrena, choroba Kawasaki, twardzina układowa, mieszana choroba tkanki łącznej, zapalenie skórno-mięśniowe [1, 2, 3, 9, 10, 13, 14, 15].

Uważa się, że u podstawy MAS leży nieprawidłowe funkcjonowanie układu immunologicznego, w tym limfocytów cytotoksycznych i komórek NK (natural killer) oraz makrofagów. Jako przyczyny brane są pod uwagę także obniżenie stężenia perforyny w limfocytach CD8 i komórkach NK oraz niedobór granzymu B [1, 2, 4, 13, 16, 17]. Dochodzi wówczas do nadmiernej niekontrolowanej aktywacji układu immunologicznego z nadmierną produkcją i uwalnianiem różnych mediatorów zapalnych, w tym interferonu-gamma, czynnika martwicy nowotworów alfa (tumor necrosis factor - TNF- $\alpha$ ), 
TABELA 1. Kryteria diagnostyczne zespołu hemofagocytarnego

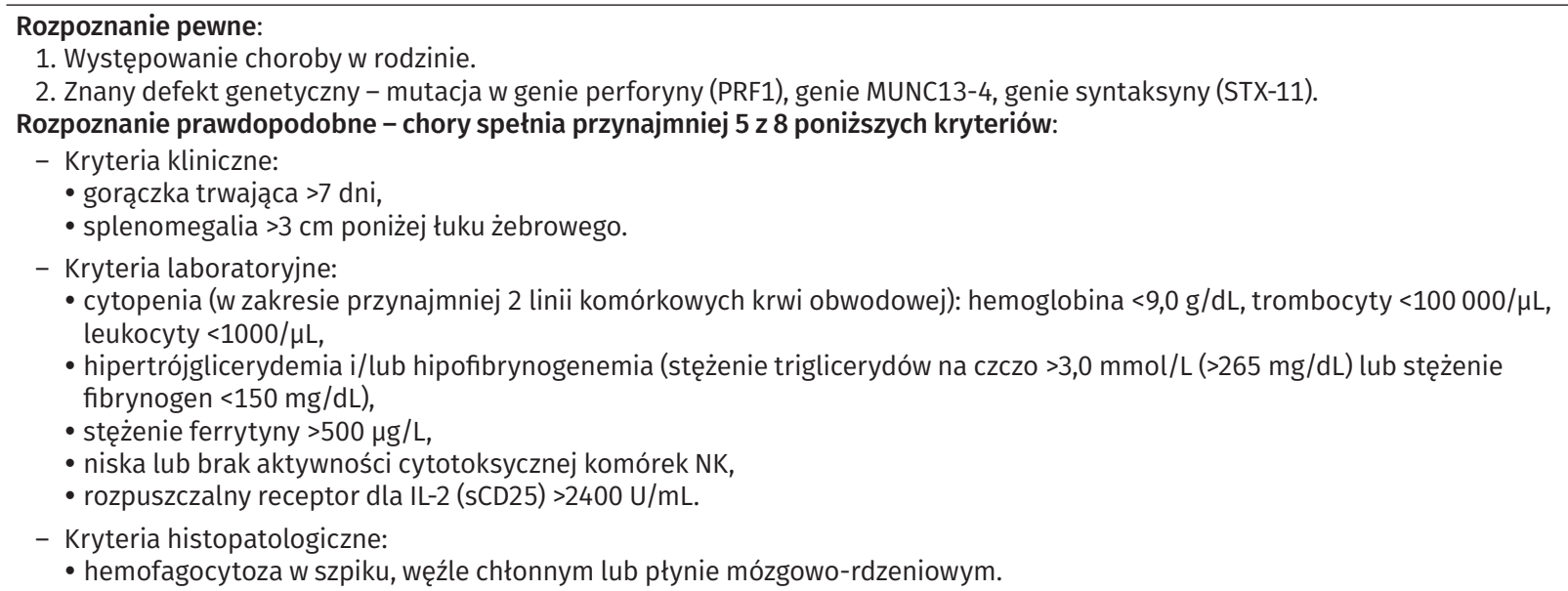

Uwaga! Kryteria z punktu 1 i 2 odnoszą się do pierwotnych HS. Kryteria kliniczne, laboratoryjne oraz histopatologiczne znajdują zastosowanie w rozpoznawaniu zarówno pierwotnych, jak i wtórnych HS.

czynnika stymulującego tworzenie kolonii granulocytów i makrofagów (granulocyte-macrophage colony stimulating factor - GM-CSF) oraz licznych interleukin (IL): IL-1, IL-6, IL-8, IL-10, IL-12, IL-18 [6, 7, 10, 12, 17]. Niekontrolowana aktywacja i proliferacja makrofagów skutkuje naciekaniem narządów m.in. szpiku kostnego, węzłów chłonnych, śledziony, wątroby, ośrodkowego układu nerwowego, a także serca [3, 10].

Obraz kliniczny może być bardzo różny, a objawy mogą narastać bardzo dynamicznie. Do najczęstszych objawów należą: gorączka utrzymująca się mimo antybiotykoterapii, powiększenie węzłów chłonnych, wątroby i śledziony, zmiany skórne (np. wysypka rumieniowo-grudkowo-pęcherzowa, plamica), objawy neurologiczne (bóle głowy, objawy oponowe, zaburzenia mowy i widzenia, padaczka, zaburzenia świadomości ze śpiączką włącznie). Mogą się także pojawić objawy zajęcia układu krążenia, oddechowego i moczowego oraz zespół wykrzepiania śródnaczyniowego. W badaniach laboratoryjnych najczęściej stwierdza się ciężką cytopenię, zaburzenia gospodarki lipidowej pod postacią hipertrójglicerydemi, hipofibrynogenemii, a także znacznie podwyższone stężenie ferrytyny. Do rzadszych należą wydłużenie czasu protrombinowego, czasu częściowej tromboplastyny po aktywacji oraz zmniejszenie stężenia czynników krzepnięcia II, VII, X i zwiększone stężenie D-dimerów. W tabeli 1 przedstawiono kryteria diagnostyczne zespołów hemofagocytarnych pierwotnych oraz wtórnych, w tym MAS. Obejmują one zarówno kryteria kliniczne, laboratoryjne, jak i histopatologiczne. Niestety, dotąd nie udało się ustalić kryteriów pozwalających odróżnić zespoły pierwotne od wtórnych $[4,5,10,12]$.

Zespół aktywacji makrofagów jest ciężkim, potencjalnie zagrażającym życiu powikłaniem chorób reumatycznych. W związku z tym ważna jest szybka diagnostyka i wczesne rozpoczęcie agresywnego leczenia. Dotychczas nie ustalono standardów leczenia MAS, dlatego wielu autorów zaleca leczenie wg protokołu HLH-2004 [1, 3, 4, 5, 6, 9, 10, 12, 18, 19]. Protokół ten zakłada leczenie wstępne - indukcyjne trwające 8 tyg., a następnie ocenę odpowiedzi na leczenie w 9 tyg. [2, 5, $10,12]$. Wówczas należy podjąć decyzję o dalszym leczeniu podtrzymującym lub ewentualnym przeszczepie macierzystych komórek krwiotwórczych (hematopoietic stem cell transplantation - HSCT) $[2,5,10,12]$. Chorzy z wtórnymi zespołami hemofagocytarnymi w większości nie wymagają HSCT, a leczenie podtrzymujące może być kontynuowane w warunkach ambulatoryjnych. Do leków stosowanych w fazie wstępnej należą: deksametazon (DXM), cyklosporyna A (CsA), etopozyd, metotreksat (MTX) - tabela 2. W zmodyfikowanych schematach leczenia stosuje się również: leki biologiczne m.in. rituksymab, etanercept oraz globuliny antylimfocytarne, dożylne preparaty immunoglobulin, metyloprednizolon, a także metody pozaustrojowego usuwania cytokin (hemofiltracja i hemodiafiltracja) $[2,5,10,12]$. W leczeniu podtrzymującym zalecane są: DXM, CsA, etopozyd $[2,3,4,5,6,9,10,12,13,20]$.

TABELA 2. Leki stosowane w leczeniu zespołów hemofagocytarnych

\begin{tabular}{ll}
\multicolumn{1}{c}{ Lek } & \multicolumn{1}{c}{ Dawka } \\
\hline Deksametazon & $\begin{array}{l}10 \mathrm{mg} / \mathrm{m}^{2} \text { (w przypadku poprawy zmniejszenie } \\
\text { dawki o 50\% co 2 tygodnie) }\end{array}$ \\
\hline Cyklosporyna & $\begin{array}{l}\text { 4-6 mg/kg w dwóch dawkach podzielonych; } \\
\text { kontrola stężenia CsA w osoczu }\end{array}$ \\
\hline Etopozyd & $\begin{array}{l}150 \mathrm{mg} / \mathrm{m}^{2} \text { 2×/tydzień przez pierwsze } \\
2 \text { tygodnie, kolejne } 6 \text { tygodni 1×/tydzień }\end{array}$ \\
\hline Metotreksat & $\begin{array}{l}15 \mathrm{mg} \text { począwszy od 3. tygodnia co tydzień } \\
\text { przez } 4 \text { tygodnie }\end{array}$ \\
\hline Eanercept & 0,4 mg/kg 2× w tygodniu, podskórnie \\
\hline Rituksymab & $\begin{array}{l}375 \mathrm{mg} / \mathrm{m}^{2} \text { 1×/tydzień; czas leczenia } \\
\text { rozważany indywidualnie }\end{array}$ \\
\hline Immunoglobuliny & 1 g/kg podawane przez 2 dni, dożylnie \\
\hline Metyloprednizolon & 3-5 pulsów 20 mg/kg lub 10 mg/kg + DXM j.w. \\
\hline CsA - cyklosporyna A; DXM - deksametazon
\end{tabular}

Protokół HLH-2004 zawiera wytyczne leczenia pierwotnych zespołów hemofagocytarnych, nie istnieją natomiast szczegółowe wytyczne w leczeniu wtórnych postaci HS. W piśmiennictwie opisywanych jest wiele odstępstw od tych standardów. Najczęściej stosowanymi lekami są glukokortykosteroidy (GKS), CsA, etopozyd, dożylne wlewy immunoglobulin, MTX, 
cyklofosfamid, leki TNF- $\alpha$, GM-CSF, a także plazmafereza [2, 3, $4,6,9,10,13,18,19]$.

Rokowanie w zespole MAS jest niepewne. Bez leczenia śmiertelność wynosi 100\%. Uważa się, że spośród wszystkich wtórnych zespołów HLH zespół aktywacji makrofagów ma najlepsze rokowanie [10, 21]. Wskaźnik śmiertelności jest wysoki i zależnie od źródła wynosi 8-38\% [10, 21]. Możliwe są także nawroty choroby, a w literaturze opisywano do 3 rzutów choroby $[17,19]$.

\section{OPIS PRZYPADKU}

W niniejszym artykule autorzy przedstawili przypadek rzadko występującego zespołu aktywacji makrofagów w przebiegu choroby Stilla. Dotyczył on chorej w wieku 19 lat z ustalonym rozpoznaniem choroby Stilla (przed 3 tyg.), z nadciśnieniem tętniczym oraz hipercholesterolemią, która stosowała w leczeniu doustny GKS, sulfasalazynę (SAS), beta-bloker (bisoprolol), statynę (simwasterol) i została przyjęta do Kliniki Reumatologii, Chorób Wewnętrznych i Geriatrii Pomorskiego Uniwersytetu Medycznego w Szczecinie (PUM) z powodu występujących od ok. 7 dni gorączek, osłabienia, wysypki początkowo swędzącej, obejmującej skórę całego ciała. Kobieta zgłaszała także występowanie nudności, wymiotów i ból w nadbrzuszu.

Podczas przyjęcia do Kliniki PUM pacjentka była w stanie ogólnym średnio-ciężkim. Jej tętno wynosiło 80/min, a ciśnienie tętnicze 130/80 mmHg. W badaniu fizykalnym uwagę zwracała: plamisto-grudkowa wysypka obejmującą całe ciało, zaczerwienienie błony śluzowej tylnej ściany gardła z nieznacznie powiększonymi migdałkami podniebiennymi, bolesność palpacyjna nadbrzusza oraz powiększona śledziona wystająca spod łuku żebrowego na $3 \mathrm{~cm}$. W wykonanych badaniach laboratoryjnych występowały: pancytopenia - leukocyty 2,3 tys./ $\mu \mathrm{L}$, stężenie hemoglobiny 9,8 g/dL, płytki krwi - 25 tys./ $\mu \mathrm{L}$, podwyższone stężenie triglicerydów $(442,0 \mathrm{mg} / \mathrm{dL})$ i ferrytyny $(44471,0 \mu \mathrm{g} / \mathrm{L})$ oraz obniżone stężenie fibrynogenu $(118,60 \mathrm{mg} / \mathrm{dL})$. Ponadto wykazano hiperbilirubinemię i zwiększoną aktywność: aminotransferazy asparaginianowej (AST) - $827 \mathrm{U} / \mathrm{L}$, aminotransferazy alaninowej (ALT) - $560 \mathrm{U} / \mathrm{L}$, fosfatazy zasadowej (ALP) - $196 \mathrm{U} / \mathrm{L}$, gamma-glutamylotranspeptydazy (GGTP) - $172 \mathrm{U} / \mathrm{L}$, a także zwiększone stężenie białka C-reaktywnego (C-reactive protein - CRP) - 78,3 mg/L przy prawidłowej szybkości opadania krwinek czerwonych i prawidłowym stężeniu prokalcytoniny. W badaniach serologicznych stwierdzono obecność przeciwciał przeciwjądrowych o plamkowym typie świecenia, w mianie 1:320, bez obecności innych przeciwciał.

W kolejnych dniach u chorej obserwowano pogłębianie się niedokrwistości, z utrzymującą się leukopenią. W trakcie hospitalizacji wykluczono zakażenia bakteryjne (ujemne posiewy krwi, moczu, wymazu z gardła), a także zakażenia wirusowe: ludzkim wirusem niedoboru odporności (human immunodeficiency virus - HIV), wirusem zapalenia wątroby typu B (WZW B), wirusem zapalenia wątroby typu C (WZW C), wirusem Epsteina-Barra (Epstein-Barr virus - EBV). W badaniu ultrasonograficznym jamy brzusznej stwierdzono powiększenie śledziony ( $w$ osi długiej 14,5 cm). W badaniu cytologicznym szpiku wykazano bardzo pobudzoną fagocytozę mogącą odpowiadać zespołowi fagocytarnemu lub fagocytozie związanej z infekcją.

Początkowo, z uwagi na pogarszający się stan chorej, rozpoczęto antybiotykoterapię oraz zastosowano wlewy dożylne z metyloprednizolonu (dwa 5-dniowe cykle, z dobową dawką metyloprednizolonu $1000 \mathrm{mg}$ ), ale nie przyniosło to poprawy. Po zgromadzeniu wszystkich wyników badań, na podstawie kryteriów diagnostycznych zespołu hemofagocytarnego rozpoznano zespół MAS. Chora spełniała następujące kryteria: kliniczne - gorączka trwająca $>7 \mathrm{dni}$, splenomegalia $>3 \mathrm{~cm}$ poniżej łuku żebrowego; laboratoryjne - pancytopenia, triglicerydy na czczo >3,0 mmol/L ( $>265 \mathrm{mg} / \mathrm{dL}$ ), fibrynogen $<150 \mathrm{mg} / \mathrm{dL}$, ferrytyna $>500 \mu \mathrm{g} / \mathrm{L}$; histopatologiczne - hemofagocytoza w badaniu cytologicznym szpiku. Po ustaleniu rozpoznania w leczeniu zastosowano: deksametazon $18 \mathrm{mg} / \mathrm{d}$ oraz cyklosporynę $2 \times 100 \mathrm{mg} / \mathrm{d}$ (wg protokołu HLH-2004). Leczenie w podanych dawkach utrzymano przez 20 dni ze znaczną poprawą stanu ogólnego chorej, jak również wyników laboratoryjnych. Z uwagi na postępującą w trakcie hospitalizacji niedokrwistość u chorej przetoczono jednostkę koncentratu krwinek czerwonych, co odbyło się bez powikłań. W związku z powikłaniami leczenia immunosupresyjnego, tj. grzybicą jamy ustnej, u pacjentki w leczeniu zastosowano również leki przeciwgrzybiczne (flukonazol).

W trakcie leczenia u chorej stwierdzono stopniową poprawę stanu ogólnego, a także poprawę parametrów laboratoryjnych. W leczeniu ambulatoryjnym zastosowano CsA w dawce dobowej $200 \mathrm{mg}(2 \times 100 \mathrm{mg})$ oraz deksametazon $-9 \mathrm{mg} / \mathrm{d}$.

Po miesiącu pacjentka zgłosiła się na ponowną hospitalizację celem oceny stanu ogólnego i ustalenia dalszego leczenia. Przy przyjęciu uwagę zwracały zwiększenie masy ciała, charakterystyczny dla egzogennego zespołu Cushinga rozkład tkanki tłuszczowej oraz rozstępy skóry powłok brzusznych i ud. W badaniach laboratoryjnych stwierdzono znaczną poprawę, m.in. leukocyty - 9,4 tys. $/ \mu \mathrm{L}$, trombocyty -236 tys. $/ \mu \mathrm{L}$, hemoglobina - 12,2 g/dL, CRP - 1,0 mg/L, normalizacja wartości parametrów wątrobowych (AST - $15 \mathrm{U} / \mathrm{L}, \mathrm{ALT}-24 \mathrm{U} / \mathrm{L}, \mathrm{APL}$ 50 U/L, GGTP - 22 U/L), stężenia fibrynogenu - 296,2 mg/dL oraz ferrytyny $-145,5 \mu \mathrm{g} / \mathrm{L}$. W leczeniu utrzymano preparat doustnej cyklosporyny A w poprzedniej dawce, natomiast zmieniono doustny preparat GKS z deksametazonu na prednizon.

Następnie chora trafiła pod stałą opiekę Przyklinicznej Poradni Reumatologicznej, gdzie w leczeniu utrzymano CsA do czerwca 2015 r., a GKS w zmniejszanych dawkach do lutego 2016 r. W trakcie leczenia ambulatoryjnego wyniki badań dodatkowych utrzymywały się w granicach normy. Pacjentka nadal pozostaje pod stałą opieką Poradni Reumatologicznej.

Zespół aktywacji makrofagów należy do schorzeń o ciężkim przebiegu i poważnym rokowaniu. W związku z tym ważne jest, aby jak najszybciej postawić rozpoznanie/podejrzenie MAS, co nie zawsze jest proste i często prowadzi do opóźnionego włączenia prawidłowego leczenia $[2,3,5$, $12,17,20,22,23]$. 
Trudność w diagnostyce powoduje przebieg kliniczny zespołu - w początkowym okresie obraz może przypominać infekcję górnych dróg oddechowych lub przewodu pokarmowego, dopiero później ujawniają się bardziej charakterystyczne objawy takie jak: gorączka niereagująca na antybiotykoterapię, powiększenie wątroby i śledziony czy limfadenopatia, żółtaczka i niespecyficzna wysypka, które również nie są objawami patognomonicznymi [6, 9, 18, 24]. W tabeli 3 przedstawiono choroby, które należy brać pod uwagę w diagnostyce różnicowej MAS z uwagi na obecność gorączki i splenomegali, co jak widać również może znacznie utrudniać diagnostykę $[17,19]$.

TABELA 3. Diagnostyka różnicowa stanów chorobowych przebiegających z gorączką i powiększeniem śledziony $[17,19]$

\begin{tabular}{|c|c|}
\hline Grupa schorzeń & Przykłady \\
\hline Zakażenia & $\begin{array}{l}\text { - wirusowe (EBV, CMV, HIV, WZW B lub WZW C, } \\
\text { parvovirus B19) } \\
\text { - bakteryjne (gruźlica, dur brzuszny, infekcyjne } \\
\text { zapalenie wsierdzia) } \\
\text { - grzybicze (inwazyjne) } \\
\text { - pasożytnicze (leiszmanioza, malaria, } \\
\text { schistosomatoza, tularemia, babeszjoza, } \\
\text { borelioza, erlichioza, bruceloza) }\end{array}$ \\
\hline $\begin{array}{l}\text { Choroby } \\
\text { reumatyczne }\end{array}$ & $\begin{array}{l}\text { - toczeń rumieniowaty układowy } \\
\text { - reumatoidalne zapalenie stawów (zespół } \\
\text { Felty'ego) } \\
\text { - choroba Stilla u dorosłych }\end{array}$ \\
\hline $\begin{array}{l}\text { Choroby } \\
\text { nowotworowe }\end{array}$ & $\begin{array}{l}\text { - chłoniaki nieziarnicze } \\
\text { - choroba Hodgkina } \\
\text { - ostre i przewlekłe białaczki } \\
\text { - szpiczak plazmocytowy } \\
\text { - mielofibroza } \\
\text { - przerzuty guzów litych }\end{array}$ \\
\hline Inne & $\begin{array}{l}\text { - amyloidoza } \\
\text { - anemia plastyczna } \\
\text { - choroba gauchera } \\
\text { - limfohistiocytoza hemofagocytarna } \\
\text { - histocytoza z komórek Langerhansa } \\
\text { - mastocytoza } \\
\text { - sarkoidzoa }\end{array}$ \\
\hline
\end{tabular}

Początkowo również ustalenie rozpoznania u chorej nie było oczywiste. W pierwszych dniach hospitalizacji wysunięto podejrzenie infekcji ogólnoustrojowej o nieustalonym punkcie wyjścia i w leczeniu zastosowano empirycznie antybiotykoterapię. Dopiero wobec braku poprawy w trakcie leczenia, jak i wobec ujemnych wyników posiewów moczu, krwi, wymazów z gardła, oraz po zebraniu wszystkich wyników badań, w tym wyniku badania cytologicznego szpiku ustalono u chorej rozpoznanie zespołu MAS na podstawie kryteriów diagnostycznych HLH (tab. 1). Chora spełniała następujące kryteria: gorączka trwająca powyżej 7 dni, splenomegalia, cytopenia, hipertrójglicerydemia, hipofibrynogenemia, hiperferrytynemia, hemofagocy toza w badaniu cytologicznym szpiku. Do leczenia włączono DXM oraz CsA wg protokołu HLH-2004. Po kilku dniach leczenia uzyskano stopniową poprawę kliniczną, jak i laboratoryjną. U kobiety w czasie 20 miesięcy od zachorowania nie obserwowano nawrotu choroby. Pacjentka nadal jest pod stałą opieką Poradni Reumatologicznej.
Zarówno autorzy, jak i sami twórcy protokołu HLH uważają, że jeśli istnieje podejrzenie zespołu MAS, choć chory nie spełnia kryteriów diagnostycznych dla pewnego rozpoznania, a dany ośrodek ma doświadczenie w rozpoznawaniu i leczeniu zespołu HLH (w tym MAS), wówczas należy rozważyć włączenie leczenie wg protokołu HLH-2004 [1, 5, 18, 24].

Należy podkreślić, iż dodatkową przeszkodą w prawidłowej szybkiej diagnostyce zespołu może być obraz szpiku, który bardzo często w początkowych etapach zespołu MAS jest prawidłowy $[1,5,25,26]$. Dopiero w późniejszym okresie nabiera cech charakterystycznych dla obrazu szpiku w przebiegu zespołu hemofagocytarnego. Należy także pamiętać, że fagocytoza stwierdzona w badaniu szpiku nie jest kryterium obligatoryjnym dla postawienia rozpoznania [5, 9, 22].

W związku z powyższym w początkowym okresie choroby szybkie rozpoznanie zespołu MAS często staje pod znakiem zapytania, opóźniając włączenie prawidłowego leczenia, co może nieść poważne skutki dla zdrowia i życia pacjenta.

Na koniec należy także dodać, iż wtórny HLH może być indukowany lekami m.in.: solami złota, MTX, SAS, niesteroidowymi lekami przeciwzapalnymi, lekami biologicznymi, a także opisywano przypadki HLH po przeszczepie komórek macierzystych czy wywołane emulsjami lipidowymi zawartymi w preparatach do żywienia pozajelitowego [2, 3, 9, 10]. W związku z powyższym za przyczynę wtórnego HLH u chorej brano pod uwagę również SAS przyjmowaną w leczeniu choroby Stilla. Jednoznaczne ustalenie przyczyny choroby nie jest możliwe, jednak za przyczynę wtórnego HLH przyjęto chorobę Stilla z uwagi na częstsze występowanie HLH w przebiegu chorób autoimmunologicznych niż indukowanych lekami.

\section{WNIOSKI}

Zespół aktywacji makrofagów jest schorzeniem o ciężkim przebiegu, poważnym rokowaniu i utrudnionej diagnostyce. W przypadku nagłego pogorszenia stanu zdrowia u pacjenta z chorobą autoimmunologiczną, bez wyraźnej przyczyny, w diagnostyce różnicowej zawsze należy pamiętać o zespole MAS i w przypadku potwierdzenia tego rozpoznania należy jak najszybciej włączyć prawidłowe leczenie.

\section{PIŚMIENNICTWO}

1. Ziętkiewicz M, Hajduk A, Wojtaczek A, Smoleńska Ż, Czuszyńska Z, Zdrojewski Z. Zespół aktywacji makrofagów - opis trzech przypadków. Ann Acad Med Stetin 2012;58(1):55-61.

2. Deane S, Selmi C, Teuber SS, Gershwin ME. Macrophage activation syndrome in autoimmune disease. Int Arch Allergy Immunol 2010;153(2): 109-20. doi: 10.1159/000312628.

3. Zoń-Giebel A, Giebel S. Zespół aktywacji makrofaga - reaktywna postać limfohistiocytozy hemofagocytarnej. Reumatologia 2008;46:21-6.

4. Kelly A, Ramanan AV. Recognition and menagment of macrophage activation syndrome in juvenile arthritis. Curr Opin Rheumatol 2007;19: 477-81.

5. Henter J-I. HLH-2004 protocol [Internet]. Histiocyte Society 2004.

6. Janka GE. Familial and acquired hemophagocy tic lymphohistiocytosis. Eur J Pediatr 2007;166:95-109. 
7. Filipovich A. Hemophagocy tic lymphohistiocytosis and rother hemophagocytic disorders. Immunol Allergy Clin North Am 2008;28:293-313.

8. Areci R. When T cells and macrophages do not talk: hehemophagocytic syndromes. Curr Opin Hematol 2008;15:359-67.

9. Buda P, Gietka P, Wieteska-Klimczak A, Książyk J. Wtórne zespoły hemofagocytarne - aktualny problem interdyscyplinarny. Wiad Lek 2013;66(2): 153-63.

10. Rojek-Margas B, Śliwowska B, Bucka J. Zespół aktywacji makrofaga. Reumatologia 2013;51(6):459-66.

11. Szczeklik A, Gajewski P. Interna Szczeklika 2014. Podręcznik chorób wewnętrznych. Kraków: Medycyna Praktyczna; 2014. p. 1722-4.

12. Klaudel-Dreszler M, Rutynowska-Pronicka O, Gietka P, Rokicki D, Dembowska-Bagińska B, Piątosa B, et al. Propozycja standardu diagnostyczno-terapeutycznego dla dzieci z podejrzeniem pierwotnego lub wtórnego zespołu hemofagocytarnego w oparciu o doświadczenia Instytutu „Pomnik Centrum Zdrowia Dziecka” w Warszawie. Stand Med 2010;7:194-205.

13. Tristano AG. Macrophage activation syndrome: a frequent but underdiagnosed complication associated with rheumatic diseases. Med Sci Monit 2008;14:27-36.

14. Ravelli A. Macrophage activation syndrome. MD. Pediatria II. Curr Opin Rheumatol 2002;14:548-552.

15. Takahashi K, Kumakura S, Ishikura H, Murakawa Y, Yamauchin Y, Kobayashi S. Reactive hemophagocytosis in systemic lapus erythematosus. Intern Med 1998;37(6):550-3.

16. Grom AA, Mellins ED. Macrophage activation syndrome: advances towards under standing pathogenesis. Curr Opin Rheumatol 2010;22:561-6.
17. Machaczka M. Specy fikacja występowania limfohistiocy tozy hemofagocytarnej w okresie wieku dorosłego. Acta Haematol Pol 2013;44:307-13.

18. Hanter JI, Horne A, Arico M, Egeer RM, Filipovich AH, Imashuku S, et al.: HLH-2004: Diagnstic and therapeutic guidelines for hemophagocytic lymphohistiocytosis. Pediatr Blood Cancer 2007;48:124-31.

19. Machaczka M, Klimkowska M. Limfohistiocytoza hemofagocytarna kiedy nadmierna odpowiedź immunologiczna wymyka się mechanizmom kontrolnym. Przypadki Medyczne 2013;45:196-205.

20. Sawhney S, Woo P, Murray KJ. Macrophage activtion syndrome: a potentially fatal complication of rheumatic disorders. Arch Dis Child 2001;85:421-6.

21. Lin C-I, Yu H-H, Lee J-H, Wang LC, Lin YT, Yang YH, et al. Clinical analysis of macrophage activation syndrome in pediatric patient with autoimmune disease. Clin Rheumatol 2012;31:1223-30.

22. Sen ES, Clarke SL, Ramanan AV. Macrophage activation syndrome. Indian J Pediatr 2016; 83(3):248-53. doi: 10.1007/s12098-015-1877-1.

23. Larroche C. Hemophagocytic lymphohistiocytosis in adults: Diagnosis and treatment. Joint Bone Spine 2012;79:356-61.

24. Pallazi DL, McClain KL, Kaplan SL. Hemophagocytic syndrome in children: an important diagnostic cnsideration in fever of unknow origin. Clin Infect Dis 2003;36:306-12.

25. Ravelli A, Grom AA, Behrens EM, Cron RQ. Macrophage activation syndrome as part of systemic juvenile idiophatic arthritis: diagnosis, genetics, pathophysiology, and treatment. Genes Immun 2012;13:289-98.

26. Atteritano M, David A, Bagnato G, Beninati C, Frisina A, Iaria C, et al. Haemophagocytic syndrome in rheumaticpatients. Systemie review. Eur Rev Med Pharmacol Sci 2012;16:1414-24. 